\title{
Georges Bataille e a comunicação soberana*
}

\section{RESUMO}

O autor investiga, neste artigo, a questão comunicacional na obra batalliana e aponta para uma leitura transdisciplinar. Bataille tem uma obra única, que desafia os modos de explicação convencionais. Joron vê na obra de Bataille mais do que uma literatura pornográfica e destaca, entre outros pontos, o que o autor - e esta é uma das maneiras com que Bataille encara a comunicação - chama de soberania, ou seja, comunicação forte.

\section{PALAVRAS-CHAVE}

comunicação

imaginário

sociologia

\section{ABSTRACT}

The author investigates in this article the subject communication in Bataille's work. According to him, Bataille has an unique work, which challenges the conventional explanation moder. Joron sees in the work of Bataille more than a pornographic literature, punctuating, among other things, his concept of sovereignty, which means, for him, strong communication.

\section{KEY WORDS}

communication

imaginary

sociology
A obra de Georges Bataille (1897-1962) está longe de ser unanimidade entre os teóricos da comunicação. Esta desconfiança é compartilhada por vários sociólogos, antropólogos, filósofos ou, ainda, economistas que só enxergam nela uma literatura de cunho ensaístico: maltratada, desorientada, pornográfica e escatológica para ser, adequadamente, incensada. Entretanto, observando-a de perto, percebe-se que toda a obra batailliana trata da problemática comunicacional. Sua leitura da comunicação é ao mesmo tempo literária, filosófica, sociológica e antropológica, desde que se aceite, claro, a idéia de uma possível comunicação transdisciplinar entre estas quatro perspectivas, além de uma quinta: "ateologia" (Klossowski, 1963, p. 750) ou, no caso, o misticismo sem deus.

O panorama deste estudo aborda alguns temas particularmente reveladores sobre a forma com que Bataille encara a comunicação. Mesmo não se tratando, de modo algum, dos meios de comunicação convencionais (imprensa, rádio e televisão) e, menos ainda, da Internet, estas análises podem nos ajudar a compreender o fenômeno da telerrealidade e, sobretudo, o da telerrealidade da violência (ou televiolência), a respeito do qual o telejornalismo policial representa uma forma de expressão bastante radical, pois questiona a identidade jornalística, sua ética, suas razões de ser e de fazer. Nós não retomaremos aqui o que já fora evocado anteriormente como sendo uma fenomenologia da televiolência (Joron, 2004, pp. 49-59), e sim veremos que o que está em jogo na violência é, particularmente, a fascinação que ela provoca a partir de suas encenações televisuais. Bataille faz uma análise sem condescendência, cujo registro desafia, freqüentemente, nossos modelos de explicação convencionais.

\section{A intimidade perdida}

As atividades no Collège de Sociologie Sacrée entre 1937 e 1939, que Bataille compartilhava com Roger Caillois e Michel Leiris, confirmam este interesse inusitado por qualquer forma de comunicação entendida como sagrada e, pois, soberana: "A sociologia sagrada pode ser considerada como o estudo não apenas das instituições religiosas, mas também do conjunto do movimento comunhal da sociedade" (Bataille, 1970, p. 291). Não é preciso dizer que é a segunda parte desta tese que nos chama a atenção. As propostas, como dissemos antes, são transdisciplinares e constituem uma espécie de metaciência dotada de uma hipermoral (Bataille, 1979, p. 171): a heterologia, ou a ciência dos corpos estranhos, dos dejetos rejeitados pela homogeneidade do mundo moderno.

Dito de outra forma, este feixe de perspectivas tem por alvo a questão da soberania na arte, na poesia, na litera-

\section{Philippe Joron}

Universidade Paul-Valéry - Montpellier III philippe.joron@univ-montp3.fr 
tura, na relação que une o ato de criação e o de recepção às emoções, mas também na sociedade existencial, na religião, na guerra, no erotismo, na festa, na vida cotidiana; em suma, nas formas de vida social que experimentam, a cada instante, o gasto improdutivo em que o sagrado é parte pregnante. Soberania, mas em relação a quê? Ao que Bataille chama vida produtiva, a homogeneidade ou esfera da atividade: como explica Philippe Audoin, comentando aqui a crítica batailliana do mundo moderno, de sua ideologia e daqueles que a defendem, "o que não é soberano é definido como servil ou subordinado. São tais comportamentos que estão ligados a um projeto, que procuram a obtenção de um resultado e cuja finalidade última é, no final das contas, salvaguardar, engrandecer, perpetuar o indivíduo, os seus, a espécie" (Audoin, 1987, p. 16). A posição situacionista de Guy Debord, ainda que posterior à demarcação batailliana, oferece, de resto, uma idéia bastante precisa deste movimento, qualificado de fulgurante por Georges Bataille na questão da soberania através da arte, através da vida como forma de arte: "A arte pode cessar de ser uma relação sobre as sensações para se tornar uma organização direta de sensações superiores. Trata-se de nós mesmos a produzirmos, e não das coisas que nos escravizam [...]. É preciso levar à destruição extrema todas as formas de pseudo-comunicação, a fim de se alcançar um dia uma comunicação real direta?" (Debord, 1958). Esta afirmação debordiana, publicada no ${ }^{\circ} 1$ da Internationale Situationniste, em junho de 1958, faz eco ao enquadramento batailliano da comunicação soberana, exposta em um artigo consagrado à interpretação, feita por JeanPaul Sartre da obra de Jean Genet, publicada na revista Critique, nº 65 e 66, em 1952. Neste artigo, que se tornará, posteriormente, um capítulo de La littérature et le mal, Georges Bataille procura estabelecer uma distinção entre a comunicação forte, que ele concebe como soberania, e a comunicação frágil, que ele relaciona a uma atividade servil: "A comunicação forte é primeira, é um dado simples, aparência suprema da existência, que se revela a nós na multiplicidade das consciências e na sua comunicabilidade" ${ }^{\prime 1}$. Esta dualidade comunicação forte/ comunicação frágil ou, para retomar a dicotomia debordiana, comunicação real direta/pseudocomunicação, aplica-se à exploração da divisão do mundo, da existência entre sagrado e profano, entre soberania e subordinação, entre consumo e consumação, entre comunhão e isolamento.

Cesura entre a condição humana e a exigência soberana... Deste rompimento, do qual cada um de nós pode ainda e sempre mensurar, apreciar o estado de tumefação - metáfora orgânica da tragédia moderna - Georges Bataille pensou na angústia da passagem à existência, soberania das lágrimas e misticismo sem deus. Assim, nesta perpétua busca por um futuro aceitável e, sobretudo, consentido encontra-se uma angústia que obseda o gesto da cotidianidade sem jamais aflorar - na efemeridade das certezas - a concretude de qualquer apazigua- mento. É uma exigência da ação, portanto, enfrentar os reflexos do desespero, transformando-os em energia solúvel, sob o risco de surpreender a legitimidade de uma tal empreitada. Mas isso importa pouco, por assim dizer, face ao trágico de um "quase", destino feito de raiva e de sangue: um destino que visita toda comunidade humana e não cessa de infringir na vida de cada dia a prova de uma finalidade na qual é preciso, porém, figurar a esperança.

A filosofia de Georges Bataille procede, assim, de uma obnubilação esclarecida face à origem do mundo, de uma perseverança quase vital que tateia suas constâncias ontológicas traduzidas em angústia, em um estado de derrelição do homem, abandonado às suas impotências. Uma origem pela qual - ou contra a qual - nós tentamos erigir um saber: um saber de combate e de ignorância. Mas este saber não chega a clarear as respostas. No limite, quanto ao saber absoluto, só podemos esperar um não-saber, aquele que "não suprime os conhecimentos particulares, mas seus sentidos" (Bataille, 1986, p. 67), aquele pelo qual "a consciência cessa de ser consciência de alguma coisa" (Bataille, 1967 [1949], p. 224). Assim, segundo G. Bataille, é rejeitando o desejo aprisionado de uma razão que salvaguarda sem explorar, tentando libertá-la, sufocando seu desejo de transcendência e de supremacia paranóica na distinção guerreira entre o sujeito e o objeto, é que o homem pode aproximar este sentimento de continuidade, de soberania, de comunicação suprema da qual ele se dissociou com sua nascença e seus aprendizados da moralidade: "A comunicação é o contrário da coisa, que se define pelo isolamento do que é possível fazer" (Bataille, 1967 [1949], p. 301). Tal é a proposição angustiante e soberana de uma intimidade perdida (Joron, 2006a, pp. 122-134)² que só a experiência do extremo pode ainda recordar através da consumação erótica, estática, poética, comunicacional: encontrar-se pela indistinção e a fusão, o esquecimento e o não-sentido; encontrar sua perda na aceitação da parte maldita; comungar, enfim, com os outros na irresponsabilidade e na inocência culpável.

No silêncio que as palavras inauguram por sua presença laboriosa, Georges Bataille penetra, depois de Friedrich Nietzsche, na hipocrisia de um mundo que se esconde e se evita. A crítica elaborada por Bataille porta, essencialmente, a indulgência, a indulgência exagerada que evoca a sociedade burguesa diante de suas próprias fraquezas, de suas conformidades não menos desenvoltas, sob o manto de um moralismo restritivo: um moralismo que, além de suas funções puramente utilitárias e, certamente, necessárias, ao lado da eligibilidade contratual e ética de sua propensão à ordem, estimula a transgressão (ultrapassando os limites), a negação pura ou mediana de práticas comumente admitidas. Não se trata, porém, e a obra de Bataille é testemunha disso, de satisfazer um ideal e, menos ainda, de confortar a imagem conceitual satisfazendo uma prevalência em uma espécie de amoralidade conveniente como valor genéri- 
co. Pode-se, certamente, conceber uma ausência total de moralidade, mas esta concepção só valeria através do subterfúgio de uma construção refletida. Definitivamente, a amoralidade não podia ser suficiente à expectativa de Bataille. Ela não ofereceria, além disso, qualquer interesse convincente ao início de sua busca. Apenas a imoralidade, entendida como hipermoralidade, podia, de acordo com ele, sustentar a comunicação soberana: " A comunicação maior só pode se fazer sob uma condição, que nós recorramos ao Mal, ou seja à violação do proibido"(Bataille, 1979, p. 314). Só a imoralidade pode convir ao gozo - daquele que não se presta a qualquer compromisso de ordem projetiva. Pode, ainda, significar a seriedade da existência que condena, mais ou menos, na culpabilidade e no arrependimento, as piedosas virtudes do utilitarismo moderno.

\section{A comunicação ao extremo}

Atormentado entre a vontade e a impossibilidade de uma comunicação verdadeira, Georges Bataille trabalhou na elaboração de uma teoria da troca, sob uma perspectiva da antropologia totalizante, por muito tempo influenciada pelos trabalhos de Marcel Mauss Essai sur le don, o "potlatch" (trabalhos que Georges Bataille comentou em La notion de dépense e La part maudite) - mas ele concebeu esta noção de troca (que ele não pode, para tanto, assimilar à essência mesmo do que ele considerava como a comunicação suprema) como parte pregnante do excesso, do exagero e da ruína. É na perspectiva da heterologia (Joron, 2006b, pp. 11-24) que ele, assim, fazia a crítica do racionalismo, que, segundo ele, só reduzia o consumo das riquezas a uma necessidade da produção:

O racionalismo representou, freqüentemente, a atividade humana como redutível à produção e à conservação dos bens. Reconheceu que o objetivo da existência era se desenvolver - ou seja aumentar (e conservar) as riquezas disponíveis. Mas toma o consumo das riquezas pelos homens como o equivalente àquela dos combustíveis pelos motores: ela não passa de um elemento necessário para a atividade produtiva (BATAILLE, 1970b, p. 155).

Georges Bataille mostra, assim, a substituição de uma lógica por outra, a que consiste em consumir para produzir em oposição à que tradicionalmente introduzia a produção como elemento subordinado ao consumo: uma economia invertida. Esta nova estandardização das relações sociais que implica o processo de racionalização não é apenas observável na identidade inovadora das trocas econômicas (bens e serviços), pois ela se afirma, também, no intercâmbio de sexo, de palavra e de imagem.

A comunicação de que fala Bataille - a que lhe diz respeito - é, visceralmente, ligada à idéia de soberania - "é um fato que não se acrescenta, de modo algum, à realidade humana, mas a constitui"(Bataille, 1986, p. 37). Ela não depende, pois, tanto de laços formais entre os indivíduos como de situações particulares que fazem do "estar-junto" uma necessidade do ser: " apenas a vida fora de si pode comunicar, escreve Mario Perniola, abrir-se propagar-se em um inesgotável movimento de prodigalidade sobre os ferimentos dos outros" (Perniola, 1982, p. 35). A comunicação inscreve-se na realidade ao mesmo tempo como consciência sacrificial e como "comunhão de solidões" (Maffesoli, 1982, p. 285). A angústia e o êxtase integram este estado de comunicabilidade que incendeia a consciência do grupo para melhor poder afirmar o perigo que o institui.

O sentido que Georges Bataille dá para a comunicação é o de que "o que comunica [...] é a parte cega que não se conhece e nem conhece" (Bataille, 1986, p.161). A comunicação se liga a uma forma da "negatividade sem uso", ou seja a uma crítica do mundo moderno, uma crítica que diz "sim" aos dejetos desse mesmo mundo. Ela não pode, pois, relevar o modo de troca:

Esta comunicação, escreve Mario Perniola, é exatamente o contrário da troca, que é a base das relações econômicas, da linguagem utilitária, do positivo; são todas suas formas (produtivas, culturais, científicas): fundada sobre a determinação quantitativa de valores e da relação, a comunicação consiste, precisamente, na ruptura de toda equivalência abstrata e no transbordamento de uma heterogeneidade qualitativa irredutível. No riso, no amor, nos momentos de efervescência coletiva... o que importa não são mais as exigências particulares, encarceradas nas suas certezas heurísticas e morais, mas o excesso de um fluxo de energia que se transmite como um turbilhão (Perniola, 1982, p. 36)

Mario Perniola lembra, aqui, as características essenciais da comunicação, aquelas que lhe dão uma realidade trágica, profundamente humana: riso, erotismo, violência, morte, exuberância, efervescência coletiva. Estes estados são, geralmente, limitados no tempo, como aquele da festa, o que evita toda propagação vertiginosa da heterogeneidade. Estes momentos de usura estão presentes na realidade social, mesmo se permanecem marginais ou são considerados como tais, no que concerne à esfera da atividade e da utilidade.

A comunicação, da forma concebida minuciosamente por G. Bataille, depois de apreendê-la segundo um modo desentravado de conhecimento (Bataille, 1976, p. 253), implica um estado de graça nos que a vivem, ou seja, um momento de soberania que os separa do servilismo e da subordinação: "A soberania é, essencialmente, a recusa de receber os limites que a crença da morte obriga a respeitar para, normalmente, assegurar, na paz laboriosa, a vida dos indivíduos" (Ibidem, p. 269).

Georges Bataille também considerou o olhar como potência comunicacional. Mas ele o converteu às noções 
de cegueira e de ofuscamento em uma concepção que valoriza as trevas do êxtase. O êxtase, o não-saber formam, assim, o "continuum" da comunicação, a que "ela mesma deixa nua, não sabendo nada" (Bataille,1986, p. 25). Conforme Bataille, só a dramatização da existência permite alcançar os estados de êxtase que fazem com que os indivíduos saiam de si mesmos, se esqueçam e se percam nesta espécie de coincidência original do Ser e do Mundo que ele denomina intimidade perdida ou estado de continuidade. $\mathrm{O}$ drama tem necessidade da angústia para se inscrever na tragédia do laço comunitário, de um irredutível medo diante do não-si, a fim de que a comunicação possa, realmente, se estabelecer em um excesso de si reencontrando a efervescência do todo:

Se nós não soubéssemos dramatizar, escreve Georges Bataille, na experiência interior, nós não poderíamos sair de nós mesmos. Nós viveríamos isolados e esmagados. Mas uma espécie de ruptura - na angústia - nos deixa no limite das lágrimas: então, nós nos perdemos, nós esquecemos nós mesmos e nos comunicamos com um além imperceptível (Bataille, 1986, p. 23).

A comunicação, sob hipótese alguma, pode se pensar, pois ela se vive. Mas a ironia do ser ("eu" não sou um outro), esta parte íntima de si-mesmo, parecida com mais ninguém, não pode ser alcançada e, assim, comunicável a não ser pelo uso da linguagem. É preciso, necessariamente, passar pelas palavras para que os vazios possam se comunicar; estes vazios que permanecem cheios de soberania no deslocamento das palavras em direção à vida. Neste caso, a dramatizatição da existência pode, no transbordamento da linguagem, saborear uma discordância entre as palavras e a experiência descrita. $\mathrm{O}$ homem deveria guardar tanto o silêncio? Parece que isto não pode ser facilmente concebível para aquele que procura chegar à única parte comunicável, a parte maldita. Para Bataille, o extremo do possível, este ponto intransponível da existência soberana não pode, em nenhum caso, ser alcançado pela falta, mas sempre pelo excesso.

Neste sentido, o sagrado está ligado à comunicação, já que ele fomenta, no seu interior, uma fusão dos seres e das coisas, uma construção da Unicidade devastadora que indica a comunhão soberana. "O sagrado, escreve Colette Peignot, é este momento infinitamente raro cuja "parte eterna" que cada ser carrega de si na vida acha-se integrado ao movimento universal" (Peignot, 1985, p. 85). Nas notas que ele redige sobre o texto Le Sacré, Georges Bataille arrisca-se em um comentário mais explícito de uma tal noção:

Esta definição ligaria o sagrado aos momentos nos quais o isolamento da vida na esfera individual é, de repente, rompido, momentos de comunicação não apenas dos homens entre eles, mas dos homens com o universo no qual eles vivem, ordinariamente, como estranhos: comunicação deveria ser entendida, aqui, no sentido de uma fusão, de uma perda de si mesmo cuja integridade só se obtém pela morte e cuja fusão erótica é uma imagem (Peignot, 1985, p. 129).

Não seria um momento sagrado sem que ele instaurasse uma comunicação verdadeira, da mesma forma que esta não pode ser efetuada sem um apelo à soberania. Este instante eterno que sacraliza a morte e a atividade erótica entra em ressonância com a soberania do Ser. Compreende-se melhor, de agora em diante, porque Georges Bataille estava possuído pela idéia de uma comunicação sobre-humana: seu mal-estar alegre o levou a ver de frente uma tal noção sem poder vivê-la efetivamente com os outros. Não há comunicação real entre os homens sem a possibilidade de uma comunidade efetiva. Ora, ele só encontrou incompreensão quando das experiências que pôde iniciar, precisamente, na esfera da sociedade secreta Acéphale: como ser Um em vários? A prática de um sacrifício podia ser considerada como única solução? O sangue derramado teria, verdadeiramente, liberado os conjurados de sua alienação, ligando-os, definitivamente, aos outros?

Esta "comunidade do impossível" - aquela que a lucidez batailliana buscava - tinha, entretanto, a vantagem de obsedar o isolamento individual e mostrar a soberania do coletivo face ao estreitamento do indivíduo: o social tem ou não um direito de olhar sobre o corpo e a consciência da unidade individual? Há direitos sobre a memória e sobre seu futuro? Não existe autonomia individual sem uma dependência plural diante do grupo. A experiência de Bataille não faz que negar o parcelamento obstinado do social dado como ossatura racional da civilização burguesa. Para ele, convém denunciar a miragem prometeica e, assim, reconciliar a dimensão sagrada do amor e da morte.

\section{Núcleo social e interatração}

Para consolidar o conjunto de sua reflexão sobre o objeto mesmo do sagrado, e, pois, da comunicação, Georges Bataille utilizará as noções de núcleo social e de interatração humana, tentando mostrar a constância na aderência das relações interpessoais. O núcleo social, definido como um conjunto de objetos, crenças, pessoas, lugares, práticas sociais tendo um caráter sagrado é, segundo Bataille, essencialmente tabu, objeto de uma repulsa: uma repulsa comum que consolida o laço social. Medo do caos, da potência dos elementos naturais, dos astros e do fogo caído do céu, daqueles a respeito dos quais se suspeita como tendo possíveis relações com o mistério das coisas: "Tudo leva a crer que os homens primitivos foram reunidos por um desgosto e por um pavor comum, por um insuperável horror, precisamente sobre o que tinha sido, primitivamente, o centro atrativo de sua união" (Bataille, 1970a, p. 311). Este núcleo social conecta o grupo em torno de valores, de práticas co- 
muns, principalmente ligadas ao sexo e à morte. Ao lado de seu caráter sagrado, é este o lugar privilegiado dos princípios organizacionais da vida social no qual escoa o imaginário coletivo. É mediação obrigatória quanto à pregnância do "viver-junto": mediação em torno da qual gravita o conjunto das interações sociais. Em direção a ele se concentram as diversas consciências relativas ao tempo e ao espaço, ponto em que se equilibram as pulsões cotidianas engendradas por uma angústia coercitiva, ela mesma mantida por uma relação conflitante entre a ironia dos pequenos acontecimentos da existência em relação à vida no seu todo e a importância deles aos olhos dos indivíduos. Perturbado pela interpenetração do nada e do todo - por seu amálgama -, o grupo deriva, constantemente, em direção ao seu próprio equilíbrio, procurando o paradoxo de um sufocamento tranqüilizante, sobre o qual tece as fibras distendidas de sua legitimidade. Ele se dá ordens de grandeza, inventa escalas de valores. Esta é, talvez, uma das contradições maiores do viver em comum: a escolha é só um valor pela falta, mas necessária. Não obstante, em certas circunstâncias, o indivíduo pode ser mariginalizado pelo grupo e, por outro lado, pode dele participar, atomizando, assim, a exclusão de outros indivíduos. Vive-se assim, simultaneamente, a renúncia e o apego na incompletude perpétua da ligação.

Este núcleo social contém o que desgosta e deprime, tudo o que é tabu, tudo o que é objeto de repulsão, mas, ao mesmo tempo, opera-se uma tensão no grupo social que não impede seu conteúdo heterogêneo, de agora em diante sacralizado: é o que Georges Bataille chama "a transformação de conteúdos depressivos em objetos de exaltação" ou, ainda, "uma transmutação paradoxal do deprimente em excitante" (Bataille, 1970a, p. 317/319). Mais precisamente: “O núcleo central de uma aglomeração é o lugar em que o sagrado esquerdo é transformado em sagrado direito, o objeto de repulsão em objeto de atração e a depressão em excitação" (Ibidem, p. 330).

A noção de interação humana, entendida como sensibilidade trópica que provoca a atração dos indivíduos entre eles, permite que Georges Bataille explore, mais adiante, o "ressort essencial da maquinaria humana" (Ibidem, 308) que provoca as formas de gregarismo em torno de um núcleo comum feito de representações, de práticas, de intenções e de pulsões. Sob um imediatismo quase exclusivamente instintivo, a interatração humana só pode existir socialmente pela mediação de um conjunto de reparos distintivos ou, mais precisamente, em função de sua passagem obrigatória ao conteúdo sagrado do "núcleo social", o que a distingue daquela dos animais, onde não se saberia, naturalmente, encontrar referência ao sagrado:

A interatração humana não é imediata: é o sentido preciso da palavra mediação, ou seja que as relações de dois homens entre eles são profundamente alteradas pelos fatos em que eles estão situados, um e outro, na órbita do núcleo central: o conteúdo essencialmente terrorífico do núcleo em torno do qual a existência de cada um deles gravita intervém como um meio termo inevitável (ibidem, 311).

Georges Bataille entrevê duas formas de interatração humana, uma de dominante sexual, outra do riso. $\mathrm{Na}$ verdade, se considerarmos que ela necessita dos vetores de reconhecimento feitos de atrações e de repulsões, se considerarmos aceitável sua ligação necessária com a verdadeira comunicação, aquela que toca o movimento comunhal da vida em sociedade, pode-se compreender estes dois pólos como sendo profundamente determinantes no acesso ao sagrado, mesmo se não pudermos reduzir este último a seus estados apenas. A partir dos exemplos dados por Bataille para ilustrar estas duas formas de interatração - uma jovem que ria no momento em que lhe fora anunciada a morte de uma pessoa conhecida e um homem que entrava em ereção toda vez que via um enterro - é possível reparar nestes dois vetores de agregação uma dominante lúdica que exerce sobre os indivíduos uma atração das mais fortes. São estes os dois pólos de interatração que constituem não só a efervescência festiva, mas também a comunicação televisa ou virtual: risos, divertimentos, qüerelas midiáticas, corpos estéticos, ironias de todo tipo. De tal maneira que a atração sexual ou o desejo que ela supõe na sua relação de prazer encontra, neste caso preciso de agregação social - direta sobre um plano festivo ou midiatizado em uma relação televisiva ou internética - um sucedâneo do ato propriamente dito: se o resultado sexual ou a consumação do ato ligado à esfera do privado, os contatos coporais - efetivos ou virtuais - são essencialmente coletivos no que tange ao roçar incessante entre os corpos que se encontram e se deixam levar por um movimento conjunto.

\section{A intensidade erótica}

A obra de Georges Bataille foi, freqüentemente, interpretada como um vasto painel humano. Porém, alguns críticos só percebem no pensamento bataillano aquele que diz respeito à atividade erótica. Mesmo que este tema não possa ser negligenciado na estrutura e na própria coesão desse pensamento, não se pode, por outro lado, refutar a totalidade dos aspectos que o complementam. Este aspecto considera o erotismo como sendo um elemento de compreensão entre outros.

O erotismo é, certamente, o limite do "societal em ato" no qual se opõem os detentores da moral. Georges Bataille descobriu nele mesmo o meio de exceder seu próprio pensamento, de exacerbar sua experiência em proveito de um universalismo estruturante. Do erotismo, ele tentou extrair uma coerência apropriada à apreciação que os homens fazem do desvio de seus caminhos de vida. Esta empreitada dolorosa, por assim dizer, que completa Le procès de Gilles de Rais e Les larmes d'Eros, resulta, parece, de uma soma bastante conseqüente das interro- 
gações esparsas diante dos paradoxos do desejo, do proibido e, logicamente, da transgressão; paradoxos que dissecam, laboriosamente, Bataille à luz de suas paixões; paradoxos que exumem dois mil anos de autoridade cristã.

Da transgressão, pode-se dizer que ela é uma violação parcial do ordenamento do grupo sobre o exagero ritualizado de uma condição profana na qual o grupo se condena ao se subordinar às exigências de produção que o sustentam. Porém, a transgressão de uma proibição pode ser socialmente reconhecida como sendo necessária à coesão do grupo. Como uma espécie de válvula de segurança, através da qual se evadem as tensões emocionais acumuladas sob o constrangimento. É o caso dos rituais iniciáticos, das festas orgiásticas ou sacrificiais pelas quais "o movimento da religião implica o paradoxo de uma regra admitindo a ruptura regular da regra, em certos casos" (Bataille, 1987, p. 110).

As religiões cristãs baniram este estado de alma e atribuiram-lhe a noção de pecado. Elas não reconheceram o caráter sagrado dos transbordamentos eróticos ou sacrificiais ao consentir, implicitamente, o simbólico do ritual: simbólico que se pode encontrar na paixão de Cristo. Na verdade, o indivíduo, sabendo-se pecador diante da autoridade moral, acha necessário expiar e, por conseqüência, entregar-se aos rigores da penitência. Assim, pois, o prazer advém do mal, porque ele entra em confronto com a vontade geral. Mas, como diz Michel Maffesoli a respeito do orgiasmo, "um princípio de realidade que recusaria todo princípio de prazer não se negaria a si mesmo?" (Maffesoli, 1985, p. 37). À exigência de uma comunidade plural que organiza a pletora sexu$\mathrm{al}$, acrescenta-se a de sua própria perpetuação em ato: "estender sem fim a orgia sacrificial". Como ainda sublinha, "esta vizinhança mística da morte e do sexo remete ao sentimento de eternidade" (Ibidem, p. 107). É verdade que no frenesi sexual, pela própria natureza de seus violentos impulsos, desenha-se a obsessão majestosa do despedaçamento existencial. Através da noção de "pequena morte", é, sobretudo, uma espécie de intuição parcelada que nos faz conhecer, de maneira substanciosa, o que poderia ser o declínio da consciência no além, de forma que "lá onde a morte se impõe, a vida se torna excessiva" (Ibidem, 107). Fatalmente, tal perspectiva conduz à indistinção destes dois estados que, é preciso lembrar, sempre foram objetos das proibições: mesmas dores diante de seus estilhaços, mesmos "prazeres", mesmos combates.

Os textos romanescos de Georges Bataille privilegiaram, freqüentemente, a "pequena morte". Ele soube, admiravelmente, expressar a estreita cumplicidade entre a torpeza dos órgãos sexuais e a decomposição cadavérica. Mas ele o fez sempre, para além do aspecto escatológico e obsceno de suas diversas descrições, respeitando a vida. É difícil ignorar as verdades da existência - as verdades da vida, como diz o senso comum - , mesmo se estas não têm a beleza ilusória que os homens lhes con- ferem. A violência e a feiúra não são valores antinômicos do bem e da beleza; o amor e a morte são apenas instantes irredutíveis da impossibilidade de seu excesso.

\section{A afirmação da vida}

Se a morte tem pouca importância em pensamento - ao menos ela não alcança esta aura reveladora na atrocidade de uma matéria orgânica se desmontando-, ela é, seguramente, este todo que envolve a concretude, o físico do ser. O que há de angustiante nela, e mesmo de exasperante? Sem dúvida, a afirmação paradoxal de uma solidão e de um estar-junto: solidão porque um ser abandona o mundo dos vivos e acentua, assim, entre os que choram, uma sensação de perda, de profunda ausência; estar-junto porque ela provoca a fusão das consciências em luto e concretiza a fundação da comunidade dos vivos. O corpo deste que não é mais objeto do sagrado do qual é preciso simbolizar a perda psicológica e moral através do desaparecimento físico:

Quando se vê um morto estendido, escreve Enel em Post-mortem, os traços calmos como se ele tivesse, enfim, encontrado o repouso depois de uma vida repleta de angústias e de decepções, treme-se, involuntariamente invadido por uma espécie de pânico que percorre o ser. Por que um cadáver provoca impressões terroríficas já que ele não pode mais lesar qualquer pessoa, sendo até menos perigoso do que alguém que está vivo? É porque ele alcançou este reino do qual não sabemos nada ${ }^{3}$

Neste compêndio cristão, que é do início do século XX, Enel parece fazer a apologia de uma morte religiosamente aceitável, carecendo de sua nebulosa ontológica analogia de uma simples etapa à vida eterna. É dito, no discurso cotidiano, que é preciso saber ficar modesto e digno quando chega o último instante, mas não se especifica que seja preciso conceber este último na renúncia. Acreditando-se no que diz Emile Cioran, que compôs em sua honra La tentation d'exister, a morte é esta "agonia triunfal" que os místicos amam desafiar na solicitude de seu êxtase :

A morte é, para eles, apenas um obstáculo a superar, uma barreira que os separa de Deus, este trampolim que lhes permite, graças ao êxtase, saltar por cima do tempo: salto instantâneo que ocasiona apenas um acesso de beatitude (Cioran, 1972, p. 235).

Mas ela deve ser considerada como objeto particular, autônomo? Deve ela, pelo contrário, ser encarada como uma presença da qual nós não poderíamos ser dissociados, despossuídos? A idéia segundo a qual ela permanece e subsiste, uma execração que nos escapa, faz com que nós a suportemos como alguma coisa que viria de fora, exterior à nossa consciência e ao nosso corpo. Ela não é, contudo, esta "ceivadora" familiar e única que 
esperava, alegre, a extinção de nossos momentos declinantes. Ela não é a morte, ela é nossa morte, aquela que se revela em nós e por nós e que não podemos, em caso nenhum, entregar ao outro, por mais próximo que ele seja.

\section{Ela (a morte) é, enfim, o único objeto que nos é revelado no irresoluto e no desconhecido.}

De fato, ela é o inevitável de uma gangrena existencial cuja vida suscita o torpor. Se há "tentação de existir", é uma tentação aberta sobre a consciência da finitude. Se a morte atribui na indistinção os valores que a sacodem, é porque ela evoca em nós o receio do desaparecimento: como se o nada se apropriasse da atmosfera do ser querido que desapareceu, degradando, assim, as lembranças que sua passagem pôde deixar em nossas memórias. Mas, para além do desaparecimento, deste intolerável que nos mina, a morte nos conduz em direção ao êxtase. Em l'érotisme, Georges Bataille descreve este movimento da seguinte forma:

\begin{abstract}
Existe um domínio onde a morte não significa mais apenas o desaparecimento, mas o movimento intolerável no qual nós perecemos apesar de nós mesmos, e que é, justamente, este a todo preço, este apesar de nós, que distinguem o momento da extrema alegria e do êxtase inominável mas maravilhoso. Se não é nada que nos ultrapassa, que nos ultrapassa apesar de nós, necessitando, a todo preço, não ser, nós não esperamos o momento insano que alongamos com todas as nossas forças e que, ao mesmo tempo, retardamos com todas as nossas forças (Bataille, 1987, pp. 261-262).
\end{abstract}

Se é verdade que a morte contribui para a combustão de cada um dos nossos instantes e que desta combustão nós retiramos nossa energia, se é verdade que ela está em ato e em pensamento no coração da nossa agitação, e nós refutamos sua presença, ela atravessa, todavia, a vida cotidiana e reafirma a exigência dos pequenos rituais que a fazem aceitável: festas, comemorações, disputas esportivas ou animalescas, nomadismo sexual, intercâmbio de palavras e de imagens, etc. Como diz Michel Maffesoli, esta é uma maneira de "viver sua morte de todos os dias"(Maffesoli, 1989, p. 173).

É preciso ser feliz como Nietzsche pretendia ser ao constatar esta negação dos homens em pensar sobre a morte? Se eles se esquivam da única certeza que pode uni-los, é porque eles utilizam incertezas na apreciação. Mesmo se a abstração da morte é bem menos pesada em termos de conseqüências, nós a perscrutamos como um presságio das trevas. E nós a receamos, nós a tememos porque a percebemos como sendo inelutável, porque nós sabemos que ela virá, num dia ou noutro, bater a nossa porta: ela é objeto de conhecimento sem que nós tenhamos, verdadeiramente, conhecimento sobre o dito objeto ${ }^{4}$. Ela é objeto de nossas inquietações nas quais procuramos ainda o sujeito. Ela é, enfim, o único objeto que nos é revelado no irresoluto e no desconhecido. E é por este motivo, talvez, que os homens procuram apagá-la de seus pensamentos, muito atentos em não mais se abandonarem à angústia que dá, entretanto, um sentido para a sua existência. Mas, segundo as análises de Max Scheler, "passar da vida à morte é ainda, de alguma forma, uma ação de ser vivo ele mesmo. "Morrer sua morte" é ainda um ato que retorna à série dos atos de vida" (Scheler, 1952, p. 31). Mesmo que nós não estejamos inteiramente de acordo com uma de suas análises que consiste em afirmar que a morte é comparável a um "desaparecimento absoluto" de uma coisa qualquer sem que ela intervenha, de forma alguma, sobre a formação de uma outra coisa, tanto do ponto de vista de sua natureza quanto de sua cultura. Max Scheler entendia o ato de morte como uma inscrição indelével do movimento da vida, o que, para Georges Bataille, era como a continuidade do Ser revelada na morte. Coloca-se em uma perspectiva compreensiva o que poderia ser o mistério hereditário. Segundo ele, nós estaríamos em busca de uma continuidade perdida, reencontrada, parcialmente, na fusão dos corpos (o êxtase ligado ao sentimento obsceno que nos ocasiona a exibição carnal).

Nós somos seres descontínuos, escreve ele em l'érotisme, indivíduos agonizantes em uma aventura ininteligível, mas nós temos a nostalgia da continuidade perdida. Nós suportamos mal a situação que nos fixa à individualidade de acasos, à individualidade perecível que nós somos. Ao mesmo tempo que nós temos o desejo angustiado da duração desta perecibilidade, nós temos a obsessão de uma continuidade primeira, que nos religa, geralmente, ao ser (Bataille, 1987, p. 21). ${ }^{5}$

Revelando-se como uma estreita passagem aberta sobre a continuidade dos seres e das coisas, a morte seria o momento decisivo de nossa busca existencial através da qual a insônia da vida se metamorfosearia em um sentido absoluto, em uma comunicação universal e eterna que se renovaria com a origem. No estranho movimento que a caracteriza, uma tal morte carrega, definitivamente, o testemunho de nosso "altéritas" (mudança), convertendo seus partidários ao imediatismo de uma comunicação absoluta.

Desta passagem unidirecional, cujo "o depois" não pode se dobrar às exigências da concepção e do conhecimento, deste ferimento existencial que pontua o caráter efêmero de nossos instantes terrestres e reafirma, por isso mesmo, nossa descontinuidade, a morte completa os vazios de uma animosidade e de uma indignação 
diante do que poderia ser a fatalidade de uma dolorosa aventura.

Quando uma vida se desfaz e nos faz assumir a fraternidade de uma comunhão que nos eleva assim como nos confina, então nós integramos, parcialmente, uma comunicação a respeito da qual nós não sabemos ainda a exata proporção: a morte revela aos vivos seu estado de descontinuidade e, nesta comunhão que os aproxima espiritualmente diante de uma lúgubre decomposição que eles podem sofrer, eles alcançam o ponto sensível de sua união, provando a eles mesmos a junção indefectível do laço social.

Mas a morte nos transporta, nos joga aos pés de nossa própria existência ou nos impulsiona para além da concepção dos espaços e dos tempos. É inevitável, de fato, que a morte esteja junto de suas características interatrativas, no centro de uma determinação comunicacional ou núcleo social. Evidentemente, Georges Bataille não é ingênuo a respeito destas duas espécies de motivações que sacodem, constantemente, a existência. Ele sabe que o positivo e o negativo coabitam nas preocupações individuais e sociais:

O ser é, constantemente, solicitado em duas direções, uma conduz à formação de ordem durável e de força conquistadora; a outra conduz ao dispêndio de força e de excesso na destruição da morte (Bataille, 1970a, p. 371).

Assim, existe no homem o desejo obsessivo da continuidade original, aquela que ele tenta reapropriar através da mediação de uma consciência científica: a perpetuação da continuidade. Nesse sentido, a salvaguarda do perecível - "esfera da atividade" - não pode, em nenhum caso, ser assimilada ao instante soberano da continuidade na medida em que o espírito humano procura este na extremidade daquela. Ora, está claro que, para Bataille, só a morte, ou seus fac-similes, revela uma tal continuidade, e, acima de tudo, a soberania que ela organiza. A angústia, o sagrado, o êxtase, o erotismo, o riso, a morte integram, do seu jeito, essa busca, essa sede do absoluto, na agonia dinâmica do gasto. Na verdade, Georges Bataille tenta exprimir a independência da continuidade do ser diante da individualidade, propriamente dita. Apenas a experiência da "perda de si" pode revelar ou, mais precisamente, manifestá-la. É o sentido desta "negação do Mistério"6 (Renard, 1987), da qual fala Jean-Claude Renard, do aniquilamento de toda noção de ser através do êxtase ${ }^{7}$, da efervescência coletiva, da irredutibilidade do sagrado, do mito da existência. De forma que o excesso dá, freqüentemente, acesso ao sagrado, mergulha os seres em um estado de graça turbulenta que os faz conhecer, para além da economia de si, o que poderia se assemelhar à comunicação soberana.

É também neste sentido que convém compreender esta metafísica do gasto, da qual Georges Bataille percorrera todos os caminhos possíveis com uma vontade de potência manifesta em que a ironia tomava, com frequiência, o ar de uma importância insuperável. "Nós diferenciamos os momentos nos quais a sorte nos carrega e, divinamente, nos clareia dos raios furtivos da comunicação, e estes momentos de desgraça nos quais o pensamento da soberania apodera-se como um bem" (Bataille, 1979, p. 306) ШFAmECOS

\section{NOTAS}

* Texto apresentado no IX Seminário Internacional da Comunicação - PUCRS/novembro de 2007.

1. Georges Bataille, Jean-Paul Sartre et l'impossible révolte de Jean Genet. In: Critique, ${ }^{\circ} 65$, octobre 1952, pp. 819-832 e n ${ }^{\circ} 66$, novembre 1952, pp. 946-961; In La littérature et le mal, CEuvres complètes, Tome IX: Paris, Ed. Gallimard, 1979, p. 312.

2. Ver também Philippe Joron (Org.), Violences et communication. Approches franco-brésiliennes des altérité communicationnelles. In: Les Cahiers de l'IRSA, ${ }^{\circ} 6$, Montpellier, SerPub. Montpellier III, décembre 2006.

3. Enel, Post-mortem, imprimé sur les presses de F. Cabasson à Toulon, pp.5-6.

4. Sobre os conceitos de " morte-punição", de " morteredenção" e de " morte-transformation ", on peut se référer à Louis-Vincent Thomas, " La rencontre de la mort et du sacré, aujourd'hui ", in Nouvelles idoles, nouveaux cultes, sous la direction de Claude rivière et Albert Piette, Paris, L'Harmattan, Coll. “ Mutations et complexité", 1990, pp. 179-201.

5. Georges Bataille. L'érotisme, Euvres complètes, Tome X, op.cit., p. 21.

6. Para o autor, O Mistério representa o que se chama comumente Deus e o misticismo de Bataille pode, então, se compreender como uma negação deste princípio misterioso.

7. Sobre esta questão nós remetemos ao texto de Jean Bruno consagrado à experiência interior de Georges Bataille, "Les techniques d'illumination chez Georges Bataille". In: Critique, No 195-196, Paris, Ed. De Minuit, 1963, pp. 706-720.

\section{REFERÊNCIAS}

AUDOIN, Philippe. Sur Georges Bataille. Paris: Ed. Actual/Le temps qu'il fait, 1987, p. 16.

BATAILLE, Georges. Le collège de sociologie. Conférence du 20 novembre 1937, CEuvres complètes, Tome II. Paris: Ed. Gallimard, 1970. 
La littérature et le mal. Euvres complètes, Tome IX. Paris: Ed. Gallimard, 1979.

L'expérience intérieure. Paris: Ed. Gallimard, coll. Tel, 1986.

La part maudite, précédée de La notion de dépense. Paris: Les Editions de Minuit, 1967 [1949].

Le rationalisme. Euvres complètes, Tome II, Paris Ed. Gallimard, 1970.

L'érotisme. Euvres complètes, Tome X, Paris: Ed. Gallimard, 1987.

. La souveraineté. In: CEuvres complètes, Tome VIII. Paris: Ed. Gallimard, 1976, p. 253.

BRUNO, Jean. Les techniques d'illumination chez Georges Bataille. In: Critique, $\mathrm{n}^{\circ} 195-196$, Paris, Ed. De Minuit, 1963, pp. 706-720.

CIORAN, Emile. La tentation d'exister. Paris: Ed. Gallimard, Coll. Idées, 1974.

DEBORD, Guy. Thèses sur la révolution culturelle. In: Internationale Situationniste, $\mathrm{n}^{\circ} 1$, juin 1958.

ENEL. Post-mortem, imprimé sur les presses de F. Cabasson à Toulon.

JORON, Philippe. Fenomenologia da televiolência. Revista Famecos, $\mathrm{n}^{\circ} 25$, Porto Alegre: EDIPUCRS, dezembro 2004, pp. 49-59.

A comunicação sacrificial. Revista Famecos, n ${ }^{\circ} 29$, dossier França: Mídia e violência (Org. JORON), Porto Alegre: EDIPUCRS, abril, 2006a, pp. 122-134.

. Heterologia e alteridade social ou a comunicação pela margem. In Contemporânea, vol. 4, $\mathrm{n}^{\circ} 1$, Salvador: Ed. UFBA, juin 2006b, pp. 11-24.

- (Org.). Violences et communication. Approches franco-brésiliennes des altérités communicationnelles. Les Cahiers de l'IRSA, $\mathrm{n}^{\circ}$ 6, Montpellier, SerPub. Montpellier III, décembre, 2006c.

KLOSSOWSKI Pierre. A propos du simulacre dans la communication de Georges Bataille. In: Critique, $\mathrm{n}^{\circ}$ 195-196. Paris: Editions de Minuit, Août-Septembre, 1963.

MAFFESOLI, Michel. La transfiguration du politique. Paris: Ed. Grasset, 1992.

. L'ombre de Dionysos. Paris: Librairie des Méridiens, Coll. Sociologies au quotidien, 1985.
. Tribus, rituels et destin. In: Une galaxie anthropologique, Hommage à Louis-Vincent Thomas. Paris: Quel Corps ?, 1989.

MARTOS, Jean-François. Histoire de l'Internationale Situationniste. Ed. Gérard Lebovici, 1989.

PEIGNOT, Colette. Ecrits posthumes (sous le titre de: Les écrits de Laure), textes rassemblés par Jérôme Peignot et le collectif Change. Paris: Ed. Pauvert, 1985.

PERNIOLA, Mario. L'instant éternel. Paris: Ed. Méridiens/ Anthropos, Coll. Sociologies au quotidien, 1982.

RENARD, Jean-Claude. L'expérience intérieure de Georges Bataille ou la négation du Mystère. Paris: Ed. Seuil, 1987.

SCHELER, Max. Mort et survie. Traduit par M. Dupuy. Paris: Ed. Aubier, Coll. Philosophie de l'esprit , 1952.

THOMAS, Louis-Vincent. La rencontre de la mort et du sacré, aujourd' hui. In: Nouvelles idoles, nouveaux cultes, sous la direction de Claude rivière et Albert Piette. Paris: L'Harmattan, Coll. Mutations et complexité, 1990, pp. 179-201. 